\title{
Epilogue: Music Teacher Education Engaging with the Politics of Diversity
}

\author{
Heidi Westerlund and Sidsel Karlsen
}

This book is published at a time of intensified social change, which is also reflected in a new epoch of music education professionalism. The need to address the dynamics of diversity is acute in many countries, not only those that struggle with the socalled migrant crisis and the often-accompanying xenophobia, populism and social disharmony. As the Spanish sociologist Manuel Castells (2010) points out, the increasing diversity of societies does not only enrich cultures, but may also hold the potential to fuel fundamentalism, radicalization and polarization. As a response, UNESCO highlights that these new challenges of "intolerance, prejudice and misunderstanding, social fragmentation, violent extremism" are "not a matter for governments alone, but for all segments of society, including universities, civil society and the private sector" (Mansouri 2017, 3). According to Castells, the sources of legitimizing identities that the nation-state once promoted are now drained away and the very concept of nation-state is called into question. Consequently, he sees the notion of political democracy, central to nationhood, to be in crisis. UNESCO therefore calls for intercultural dialogue to enhance learning to live together (Mansouri 2017), and the European Union urges its member-states to establish visions and policies that foster intercultural co-existence, collaboration and education to help in the complex and challenging work of building a common ground for the future (Vision Europe Summit 2016).

This new epoch therefore warrants attention by music educators who may consider themselves musically omnivorous and multicultural but who still, more often

H. Westerlund ( $\square)$

Sibelius Academy, University of the Arts Helsinki, Helsinki, Finland

e-mail: heidi.westerlund@uniarts.fi

S. Karlsen

Music Education and Music Therapy Department, Norwegian Academy of Music,

Oslo, Norway

e-mail: sidsel.karlsen@nmh.no

H. Westerlund et al. (eds.), Visions for Intercultural Music Teacher Education,

Landscapes: the Arts, Aesthetics, and Education 26,

https://doi.org/10.1007/978-3-030-21029-8_14 
than not, prefer a politically and socially neutral stance for transmitting musical content. If, as the UNESCO and European Union policies pinpoint, the situation requires an urgent need for reflexivity in terms of who 'we' are, as music education professionals, and an explication of what our stances might be in navigating cultural diversity (Westerlund 2017), we need to focus strongly on the task of clarifying this to ourselves, our professional communities, and the surrounding world. It simply makes it urgent to put this front and center in developing individual and collective professional understandings of how to respond to the quest for solidarity (Karlsen and Westerlund 2015). This new communicative, collaborative ideal cannot be one that is enacted for others, or imposed upon people, but is one that arises through construction and action that is negotiated together with all parties involved. Accordingly, new community values are sought and the notion of who 'we' are in music education, is vulnerable, and must be under constant (re)construction (Westerlund 2017; Westerlund et al. 2017). This requires an enhanced understanding from music teachers, as our profession cannot simply assume that shared values and communities develop as a consequence of joint music-making or the inclusion of certain repertoires, as many of the authors of this book have argued. A 'culture of diversity' itself (Zapata-Barrero 2015, 8) needs to be remade.

Whilst this book serves as just one illustration of how politics, policy and the idea of the nation-state together create the backdrop, and construct our future visions, of music teacher education on the local and national levels, we hope that the culture of diversity becomes a central focus of the profession as we approach the 2020s. The chapters have shown how intercultural interaction can reconstruct what is positioned as the 'mainstream.' Shared, taken-for-granted assumptions of what music teacher education is, and ought to be, about, are thus replaced with a focus on interculturality at the core, rather than the optional periphery, of music teacher education. There is a need to consider teachers' identity work beyond poly-cultural musical omnivorousness, characteristic of much multicultural music education, and to reconstruct teacher education through collective identity work which strives towards creating solidarity in and through 'imagined communities' in a culture of diversity (Westerlund 2017). This kind of music teachers' identity work is not grounded in an assumed neutrality of musical knowledge but is a resource for teacher reflexivity that can face ambivalence, paradoxes, social struggle, and ethics (Karlsen et al. 2016). We see that a time is approaching when we can, and we need, to reposition music educators at the heart of societal transformation, as we work towards 'imagined communities' where living with diversity becomes an everyday, and ethical, way of living together.

As a whole, this book shows how music teacher education, and equally teacher education in general, is penetrated by various political interests. While this fact may often have been largely forgotten or obscured by music teacher educators and others working within higher music education, policy scholars remind us that teacher education, of all kinds, works as a device to achieve certain goals, driven by both economic interests and "fears of increasingly serious internal disaffection among marginalised groups in divided societies" (Bates and Townsend 2007, 727). As Bates and Townsend argue, 
these fears of economic or social disaster seem to create political and moral panics in which education systems (and schools and teachers and teacher educators) are blamed for failing to respond to changed circumstances in appropriate ways. Therefore, the political argument runs, only a significant transformation of schools depends upon the transformation of teachers. The transformation of teachers depends upon the transformation of teacher education. Thus, teacher education has become a political issue. $(2007,727)$

Bates and Townsend further suggest that it is now commonly accepted that teachers should be educated by fostering pedagogy within the context of curricular practices that are responsive also to the cultural understandings of pupils and their communities without however subsuming their subject to the tyranny of particular traditions or communities $(2007,733)$. It is therefore important also for music teachers to be able to see beyond musical practices and their community values as these values cannot necessarily guide us when responding to the quest for solidarity in educational contexts.

The authors in this volume have shown the various ways that higher music education and music teacher education appear as 'path-dependent,' in other words are limited by decisions made in the past and therefore bound to reproduce existing practices to a much larger extent than would be beneficial for sustainable and fruitful development. Going beyond this, they also illustrate how challenging, or even painful, envisioning out-of-the-box alternatives can be in an expert, professional community. Yet, it is clear that each of the authors are also incredibly hopeful for the transformation of institutional culture. Indeed, we argue that the wider change in music teacher education requires a change in our understanding of what constitutes expertise in professional communities. Instead of simply viewing knowing how to teach music as contained within individual mental processes, it could also be seen as relational and transactional, "connected to a role in a workplace community" (Hakkarainen et al. 2004). In this way, politics of diversity could be deliberated collaboratively, together. This volume aims to initiate such collective professional activities towards developing a reflexive music teacher education that centers intercultural collaboration in creating knowledge-building communities in which knowledge does not mean certainty but engagement with uncertainty. The book illustrates how intercultural interaction in music teacher education can break the silos of what is considered 'professional knowledge' as it: highlights the need to question; actively attends to issues from multiple perspectives; and locates teachers on "a path of continuing professional development" (Forrester and Draper 2007, 388). It promotes an inquiry stance (Cochran-Smith and Lytle 2001) that is "linked not only to high standards for the learning of all students but also to social change and social justice and to the individual and the collective professional growth of teachers" (Cochran-Smith and Lytle 2001, 46).

We have previously argued that the mainstream discourses of diversity in music education are ocularcentric, and that we need a far more heterogeneous and kaleidoscopic understanding of diversity in music education in order to do justice to the "complexity of intercultural negotiation through knowledge production" (Westerlund and Karlsen 2017, 78). Consequently, employing a lens of interculturality is insufficient, given that such a perspective may too become one-sided and result in 
professional blindspots. Still, this catalyzing conceptual tool may provide much needed new entry-points from where educators and scholars might approach the professional challenges of twenty-first-century music teaching and learning and instigate the necessary changes in music teacher education programs. Our hope is that the book has illustrated that this change is indeed achievable, through small steps that allow music education institutions to break their path-dependency.

Finally, we would like to thank the Academy of Finland for making possible not just the editorial work of this book but the research and practical work described in many of its chapters, through a substantial research grant for the project Global visions through mobilizing networks: Co-developing intercultural music teacher education in Finland, Israel and Nepal (project number 286162). This grant has not only allowed us, but also forced us, to reposition ourselves and assume a stance on many of the questions and topics raised within these pages. It has invigorated our teaching, discussions, thinking and writing in new and unforeseen directions as we have had the opportunity to collaborate with many colleagues around the world. Due to the project's evolving design, we anticipate that these collaborations, and new ones, will continue to challenge us and feed our thoughts for many years to come.

\section{References}

Bates, R., \& Townsend, T. (2007). The future of teacher education. In T. Townsend \& R. Bates (Eds.), Handbook of teacher education: Globalization, standards and professionalism in times of change (pp. 727-734). Dordrecht: Springer.

Castells, M. (2010). The power of identity (2nd ed.). Oxford: Wiley-Blackwell.

Cochran-Smith, M., \& Lytle, S. L. (2001). Beyond certainty: Taking an inquiry stance on practice. In A. Lieberman \& L. Miller (Eds.), Teachers caught in the action: Professional development that matters (pp. 45-58). New York: Teachers College Press.

Forrester, V., \& Draper, J. (2007). Newly qualified teachers in Hong Kong: Professional development or meeting one's fate? In T. Townsend \& R. Bates (Eds.), Handbook of teacher education. Globalization, standards and professionalism in times of change (pp. 381-390). Dordrecht: Springer.

Hakkarainen, K., Palonen, T., Paavola, S., \& Lehtinen, E. (2004). Communities of networked expertise: Professional and educational perspectives. Amsterdam: Elsevier Science.

Karlsen, S., \& Westerlund, H. (2015). Music teachers' repertoire choices and the quest for solidarity: Opening arenas for the art of living with difference. In C. Benedict, P. Schmidt, G. Spruce, \& P. Woodford (Eds.), The Oxford handbook of social justice in music education (pp. 372387). New York: Oxford University Press.

Karlsen, S., Westerlund, H., \& Miettinen, L. (2016). Intercultural practice as research in higher music education: The imperative of an ethics-based rationale. In P. Burnard, E. Mackinlay, \& K. Powell (Eds.), The Routledge international handbook of intercultural arts research (pp. 369-379). London: Routledge.

Mansouri, F. (Ed.). (2017). Interculturalism at the crossroads, comparative perspectives on concepts, policies and practices. Paris: UNESCO Publishing.

Vision Europe Summit (2016, November). From fragmentation to integration: Towards a "whole-of-society" approach to receiving and settling newcomers in Europe. Lisbon. 
Westerlund, H. (2017). Visions for intercultural teacher identity in C21st super diverse societies. In P. Burnard, V. Ross, H. J. Minors, K. Powell, T. Dragovic, \& E. Mackinlay (Eds.), Building intercultural and interdisciplinary bridges: Where theory meets research and practice (pp. 12-19). Cambridge: BIBACC Publishing.

Westerlund, H., \& Karlsen, S. (2017). Knowledge production beyond local and national blindspots: Remedying professional ocularcentrism of diversity in music teacher education. Action, Criticism, and Theory for Music Education, 16(3), 78-107. https://doi.org/10.22176/ act16.3.78.

Westerlund, H., Partti, H., \& Karlsen, S. (2017). Identity formation and agency in the diverse music classroom. In R. MacDonald, D. Hargreaves, \& D. Miell (Eds.), Oxford handbook of musical identities (pp. 493-509). Oxford: Oxford University Press.

Zapata-Barrero, R. (2015). Interculturalism: Main hypothesis, theories and strands. In R. ZapataBarrero (Ed.), Interculturalism in cities: Concept, policy and implementation (pp. 3-19).

Open Access This chapter is licensed under the terms of the Creative Commons Attribution 4.0 International License (http://creativecommons.org/licenses/by/4.0/), which permits use, sharing, adaptation, distribution and reproduction in any medium or format, as long as you give appropriate credit to the original author(s) and the source, provide a link to the Creative Commons licence and indicate if changes were made.

The images or other third party material in this chapter are included in the chapter's Creative Commons licence, unless indicated otherwise in a credit line to the material. If material is not included in the chapter's Creative Commons licence and your intended use is not permitted by statutory regulation or exceeds the permitted use, you will need to obtain permission directly from the copyright holder.

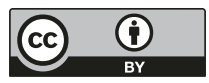

